\title{
PENINGKATAN HASIL BELAJAR MATEMATIKA SISWA MELALUI MODEL PEMBELAJARAN KOOPERATIF TIPE INVESTIGASI KELOMPOK
}

\author{
Suharto $^{1}$, Dian Apriani ${ }^{2}$ \\ ${ }^{1}$ Guru SMP Negeri 17 Palembang \\ ${ }^{2}$ Universitas Tamansiswa Palembang \\ *dian_Apriani@unitaspalembang.ac.id
}

\begin{abstract}
The formulation of the problem in this study is whether students' mathematics learning outcomes can be improved through the Group Investigation type cooperative learning model in class VIII.5 of SMP Negeri 17 Palembang. The method that I use in this research is classroom action research method. Data collection was carried out using test techniques. Analysis conducted with basic statistics. The average value of learning outcomes in Cycle I was 61.87 increasing to 76.34 in Cycle II. It can be concluded that an increase occurred after the use of cooperative learning models of group investigation type.
\end{abstract}

Key Words: Cooperative Learning Models, Group Investigations, Mathematics

\begin{abstract}
Abstrak: Rumusan masalah dalam penelitian ini adalah apakah hasil belajar matematika siswa dapat ditingkatkan melalui model pembelajaran kooperatif tipe Investigasi Kelompok di kelas VIII.5 SMP Negeri 17 Palembang. Metode yang penulis gunakan dalam penelitian ini adalah metode classroom action research atau penelitian tindakan kelas. Pengumpulan data dilakukan dengan teknik tes. Analisis yang dilakukan dengan statistik dasar. Nilai rata-rata hasil belajar pada Siklus I adala 61,87 meningkat menjadi 76,34 pada siklus II. Hal ini dapat disimpulkan bahwa terjadi peningkatan setelah digunakannya model pembelajaran kooperatif tipe investigasi kelmpok.
\end{abstract}

Kata Kunci: Model Pembelajaran Kooperatif, Investigasi Kelompok, Matematika

\section{PENDAHULUAN}

Matematika merupakan ilmu universal yang mendasari perkembangan teknologi modern, mempunyai peran penting dalam berbagai disiplin dan memajukan daya pikir manusia. Mata pelajaran matematika perlu diberikan kepada semua peserta didik, mulai dari sekolah dasar untuk membekali peserta didik dengan kemampuan berfikir logis, analitis, sistematis, kritis dan kreatif, serta kemampuan bekerjasama. Kompetensi tersebut diperlukan agar peserta didik dapat memiliki kemampuan memperoleh, mengelola dan memanfaatkan informasi untuk bertahan hidup pada keadaan yang selalu berubah, tidak pasti, dan kompetitif (Depdiknas, 2006). Mengingat pentingnya matematika itu dalam mempersiapkan sumber daya manusia yang unggul dan handal maka dalam mempelajarinya diperlukan suatu pembelajaran yang tepat agar tujuan pembelajaran dapat tercapai seperti yang diharapkan. 
Usaha untuk mencapai tujuan pembelajaran ditempuh melalui penyelenggaraan pembelajaran yang merupakan salah satu tugas utama guru dimana pembelajaran diartikan sebagai kegiatan yang ditujukan untuk membelajarkan siswanya. Setiap proses pembelajaran selalu menghasilkan hasil belajar, pentingnya hasil belajar pada pembelajaran matematika di SMP karena merupakan satu faktor yang menentukan keberhasilan siswa.

Saat ini hasil belajar matematika siswa kelas VIII.5 SMP Negeri 17 Palembang masih rendah, berdasarkan hasil ulangan harian semester ganjil tahun pelajaran 2016/2017 pada materi Teorema Pythagoras, dari 36 orang siswa hanya 12 orang yang mendapat nilai $\geq 75$ selebihnya 24 orang siswa mendapat nilai <75, ketuntasan belajar yang dicapai baru 33,3\%, belum mencapai ketuntasan klasikal.

Dengan rendahnya hasil belajar yang diperoleh, penulis menyadari banyak sekali faktor yang mempengaruhi ketidakberhasilan pengajaran matematika, salah satu faktor penyebabnya adalah karena pembelajaran yang dilaksanakan kurang tepat.

Pengalaman penulis mengajar selama ini, pengajaran di kelas masih berpusat pada guru sebagai sumber utama pengetahuan. Siswa kurang terlibat secara aktif dalam proses pembelajaran, metode yang digunakan kurang bervariasi serta media pembelajaran yang kurang tepat sehingga siswa kurang tertarik belajar matematika. Akibat proses belajar terpusat pada guru dan siswa menerima secara pasif konsep yang tertanam tidak bertahan lama atau sangat sedikit konsep yang ada pada siswa, akhirnya hasil belajar siswa kurang memuaskan. Penyelenggaraan pembelajaran matematika tidaklah mudah, fakta menunjukkan bahwa para siswa mengalami kesulitan dalam mempelajari matematika (BSNP, 2007). Untuk itu perlu dicari alternatif pembelajaran yang dapat memberikan kesempatan kepada siswa untuk ikut terlibat secara aktif dalam proses pembelajaran.

Siswa akan mempelajari matematika jika mereka mempunyai motivasi, dengan caranya sendiri, melalui kerja dengan temannya, dan memerlukan konteks yang berbedabeda (Depdiknas, 2005) dan berdasarkan penelitian Suryadi (1999) dan Isjoni (2009) menyatakan model pembelajaran yang efektif untuk meningkatkan kemampuan berfikir siswa adalah cooperative learning. Agar pembelajaran matematika menjadi pembelajaran yang aktif, kreatif dan menyenangkan dapat dilakukan dengan berbagai cara, salah satu cara adalah melalui penerapan pembelajaran kooperatif tipe investigasi kelompok

\section{Menurut Aunurrahman}

(2009:176) keberhasilan proses pembelajaran merupakan muara dari seluruh aktifitas yang dilakukan guru dan siswa. Artinya, apapun bentuk kegiatan-kegiatan guru mulai dari merancang pembelajaran, memilih dan menentukan materi, pendekatan, strategi dan metode pembelajaran, memilih dan menentukan teknik evaluasi, semuanya diarahkan untuk mencapai keberhasilan belajar siswa.

Keberhasilan proses pembelajaran tidak terlepas dari kemampuan guru menerapkan modelmodel pembelajaran yang berorientasi pada peningkatan intensitas keterlibatan siswa secara efektif di dalam proses pembelajaran. Pengembangan model pembelajaran yang tepat pada dasarnya bertujuan untuk menciptakan kondisi pembelajaran yang memungkinkan 
siswa dapat belajar secara aktif dan menyenangkan sehingga siswa dapat meraih hasil belajar dan prestasi yang optimal. Berdasarkan hasil penelitian Haffidianti(2011:66) model pembelajaran group investigation dapat meningkatkan hasil belajar matematika siswa.

Berdasarkan latar belakang masalah yang telah diuraikan di atas maka tujuan dari penelitian tindakan kelas ini adalah untuk meningkatkan hasil belajar matematika siswa melalui kegiatan pembelajaran koperatif tipe Investigasi Kelompok di kelas VIII.5 SMP Negeri 17 Palembang.

\section{TINJAUAN TEORETIS}

\section{Model Pembelajaran Kooperatif (Cooperative Learning)}

Model pembelajaran adalah suatu pola atau rencana yang sudah direncanakan sedemikian rupa dan digunakan untuk menyusun kurikulum, mengatur materi pelajaran dan memberi petunjuk kepada pengajar di kelasnya (Isjoni, 2009). Dalam penerapannya model pembelajaran yang digunakan harus sesuai dengan kebutuhan siswa dan relevansinya dengan pencapaian tujuan pengajaran.

Model pembelajaran kooperatif merupakan pembelajaran yang secara sadar dan sengaja mengembangkan interaksi yang saling asuh antar siswa untuk menghindari ketersinggungan dan kesalahpahaman yang dapat menimbulkan permusuhan (Kunandar, 2008). Hal senada juga diungkapkan oleh Isjoni (2009), bahwa pembelajaran kooperatif adalah kegiatan belajar mengajar secara kelompok-kelompok kecil, siswa belajar dan bekerjasama untuk sampai kepada pengalaman belajar yang optimal, baik pengalaman individu maupun pengalaman kelompok.
Dari kedua pendapat di atas maka peneliti dapat menyimpulkan bahwa model pembelajaran kooperatif adalah suatu model pembelajaran dimana kegiatan pembelajaran dilakukan dalam kelompok-kelompok kecil dimana siswa belajar dengan cara bekerjasama untuk mencapai pengalaman belajar yang optimal, baik pengalaman individu maupun pengalaman kelompok.

Adapun unsur-unsur pembelajaran kooperatif minimal ada empat macam, yaitu saling ketergantungan positif, interaksi tatap muka, akuntabilitas individual dan keterampilan menjalin hubungan antar pribadi.

\section{Tipe Investigasi Kelompok}

Joice, Weil, dan Calhoun (Aunurrahman, 2009) mendeskripsikan empat kategori model pembelajaran, yaitu rumpun model sosial (social family), pengolahan informasi (informasi proceeding family), model personal (personal familiy), dan model system prilaku . Adapun yang temasuk dalam kelompok model social yaitu, Group investigation (Investigasi Kelompok).

Menurut Killen (Aunurrahman, 1998) memaparkan beberapa ciri essensial investigasi kelompok sebagai pendekatan pembelajaran adalah:

(a) Para siswa bekerja dalam kelompok-kelompok kecil dan memilki independensi terhadap guru;

(b) Kegiatan-kegiatan siswa terfokus pada upayamenjawab pertanyaan yang telah dirumuskan;

(c) Kegiatan belajar siswa akan selalu mempersaratkan mereka untuk mengumpulkan sejumlah data, menganalisisnya dan mencapai beberapa kesimpulan;

(d) Siswa akan menggunakan pendekatan yang beragam di dalam belajar; 
(e) Hasil-hasil dari penelitian siswa dipertukarkan di antara seluruh siswa.

Pembelajaran kooperatif tipe Investigasi Kelompok menurut Trianto (2007), Pembelajaran kooperatif tipe investigasi kelompok meliputi :
a) Memilih Topik
b) Perencanaan Kooperatif;
c). Implementasi;
d). Analisis dan Sintesis;
e). Presentasi
f). Evaluasi

\section{Langkah-Langkah Pembelajaran Kooperatif Tipe Investigasi Kelompok}

1. Guru memanggil ketua- ketua kelompok untuk membahas satu materi yang berbeda setiap kelompoknya. Guru menjelaskan maksud pembelajaran dan tugas kelompok, masing- masing kelompok terdiri dari dua sampai enam anggota kelmpok.

2. Masing-masing kelompok membahas materi yang sudah ada secara kooperatif, mengerjakan LKS yang sudah disediakan, dan menyusun materi presentasi (Guru berkeliling memantau aktivitas siswa dan memberikan dorongan bagi kelompok yang mengalami kesulitan).

3. Presentasi kelompok ke depan kelas secara bergantian, sedangkan kelompok yang lain menanggapi.

4. Setelah kegiatan presentasi berakhir, guru mengevaluasi kontribusi kelompok terhadap kelas dan memberi penjelasan singkat tentang materi yang telah dibahas oleh masing-masinng kelompok.

5. Siswa diberikan soal-soal latihan, agar siswa lebih dapat memahami tentang materi yang sudah dibahas. atau pertanyaan kepada seluruh siswa secara individual.
6. Guru bersama siswa membuat rangkuman hasil presentasi kelompok, di akhir pertemuan siswa diberi tugas pekerjaan rumah.

\section{METODOLOGI PENELITIAN}

Penelitian Tindakan kelas ini dilaksanakan di kelas VIII.5 SMP Negeri 17 Palembang. Dimana jumlah siswa adalah 36 orang terdiri dari 18 siswa laki-laki dan 18 siswa perempuan.

Metode yang penulis gunakan dalam penelitian ini adalah metode classroom action research atau penelitian tindakan kelas.

Penelitian tindakan kelas memiliki disain yang berupa daur spiral dengan empat langkah utama, yaitu: perencanaan, tindakan, pengamatan dan refleksi.

Penelitian Tindakan Kelas ini dilaksanakan melalui beberapa siklus, setiap siklus mempunyai langkahlangkah sebagai siklus spiral meliputi:

a) perencanaan, b) tindakan, c) observasi, d) refleksi dan perencanaan ulang sebagai dasar untuk pemecahan masalah.

Teknik analisis data yang digunakan dalam penelitian ini adalah teknik analisis deskriptif kuantitatif.

\section{HASIL DAN PEMBAHASAN}

Penelitian menggunakan materi kubus, balok dan bagian-bagiannya serta menentukan ukurannya, dengan kompetensi dasar : Mengidentifikasi sifat-sifat kubus, balok, prisma dan limas serta bagian-bagiannya; Menghitung luas permukaan dan volume kubus, balok, prisma dan limas.

Pelaksanaan penelitian dimulai dengan memberikan pertanyaanpertanyaan lisan untuk mengetahui penguasaan siswa terhadap konsep bangun-bangun ruang. Kemudian 
dilanjutkan dengan memberikan model bangun-bangun ruang, yaitu kubus, balok, prisma dan limas. Siswa diminta untuk mengamati bangun-bangun ruang tersebut secara berkelompok.

Pada pertemuan berikutnya, perencanaan program pembelajaran mengarah ke perbaikan terhadap kesulitan yang dihadapi siswa. Proses penelitian ini merupakan siklus kegiatan yang terdiri dari Perencanaan tindakan, Pelaksanaan tindakan, Observasi/pengamatan tindakan dan refleksi terhadap tindakan

Pengumpulan data pada penelitian ini dilakukan dengan observasi dan tes. Penelitian ini dilaksanakan dalam 2 siklus dengan 7 kali pertemuan, yang masing-masing pertemuan menyajikan kompetensi dasar yang berbeda dan pada akhir setiap siklus siswa diberi tes tertulis berupa soal bentuk uraian sebanyak lima soal.

Model pembelajaran kooperatif tipe investigasi kelompok digunakan dengan tujuan agar siswa mampu menginvestgasi sendiri materi yang akan dipahami sehingga siswa benarbenar paham akan konsep dari materi tersebut. Pengetahuan dan keterampilan siswa diperoleh dari usaha siswa mengkonstruksi sendiri pengetahuan dan keterampilan baru ketika ia belajar. Dengan model pembelajaran kooperatif tipe inverstigasi kelompok siswa akan lebih kreatif, terampil, dan mandiri.

Dengan model pembelajaran kooperatif tipe investigasi kelompok, pembelajaran lebih bermakna bagi siswa karena siswa bekerja dan mengalami sendiri pengetahuan yang didapat. Peneliti hanya sebagai pengarah dan pembimbing untuk mewujudkan potensi siswa dan membantu siswa mencapai keunggulan akademik yang lebih baik.

Dari data hasil penelitian Siklus I

dan Siklus II, terlihat adanya peningkatan hasil belajar siswa dalam pembelajaran, sehingga penelitian berakhir pada Siklus II karena nilai rata-rata hasil tes siswa sudah baik dan ketuntasan belajar secara klasikal sudah tercapai. Hasilnya dapat dilihat pada tabel 4.3 .

Berdasarkan nilai rata-rata hasil tes pada Siklus I adalah 61,87 dengan persentase ketuntasan belajar $52,7 \%$. Pada Siklus II nilai rata-rata hasil tes 76,34 dengan persentase ketuntasan belajar $86,1 \%$.

\section{SIMPULAN DAN SARAN}

Dari hasil penelitian dapat disimpulkan bahwa hasil belajar matematika siswa dapat ditingkatkan melalui model pembelajaran kooperatif tipe Investigasi Kelompok di kelas VIII.5 SMP Negeri 17 Palembang. Adapun Nilai rata-rata hasil tes dari Siklus I dan Siklus II adalah 61,87 dan 76,34. Terjadi peningkatan 14,47. Persentase ketuntasan belajar pada Siklus I dan II adalah $52,7 \%$, dan $86,1 \%$.

\section{DAFTAR PUSTAKA}

Arikunto, Suharsimi. 2006. Penelitian Tindakan Kelas. Jakarta: Bumi Aksara.

Kurikulum Berbasis Kompetensi. CV. Tamita Utama : Jakarta Aunurahman. 2009. Belajar dan Pembelajaran. Bandung: Alfabeta.

Depdiknas. 2006. Undang-Undang RI Tentang Guru dan Dosen serta Profesional

Direktorat Jenderal Pendidikan Dasar dan Menengah. 2003. Penelitian

Tindakan Kelas. Jakarta: Depdiknas.

Direktorat Jenderal Pendidikan Dasar dan Menengah. 2005. Pelatihan Terintegrasi Berbasis Kompetensi Guru Mata 
Pelajaran Matematika. Jakarta: Depdiknas.

Djaali. 2008. Psikologi Pendidikan. Jakarta: Bumi Aksara.

Haffidianti, Yunita. 2011. Penerapan Model Pembelajaran Group Investigation ( GI) Dalam Upaya Meningkatkan Hasil Belajar Peserta Didik Pada Materi Pokok Bangn Ruang Kelas VIII F MTs Negeri 1 Semarang Tahun Pelajaran 2010/2011, Semarang: Skripsi.

Hamalik, Oemar. 1994. Kurikulum dan Pembelajaran. Jakarta: Bumi Aksara.

Isjoni. 2009. Cooperative Learning. Bandung: Alfabeta.

Iswandi. 2010. Penerapan Metode Pembelajaran Kooperatif Model Group Tentang Tumbuhan Hijau Kelas $V \quad S D N$ Temenggungan 02 Kecamatan Udanawu Kabupaten Blitar. Blitar: PTK (Tidak Dipublikasikan).

Johnson, Elaine, B. 2006. Contextual Teaching \& Learning. Bandung: MLC.

Kunandar. 2008. Guru professional, Implementasi Kurikulum Tingkat satuan Pendidikan (KTSP) dan Persiapan Menghadapi Sertifikasi Guru. Jakarta: Raja Grafindo Persada.

Purwanto, Ngalim. 1990. Prinsipprinsip dan Teknik Evaluasi Pengajaran. Bandung: PT. Remaja Rosdakarya.

Renita, Dina. 2008. Meningkatkan Hasil Belajar Matematika melalui Pendekatan Contextual Teaching and Learning (CTL) di SMP Negeri 1 Payaraman Kelas VIII.B. Palembang : PTK (Tidak Dipublikasikan).

Rosyah, Lira. 2004. Studi Pembelajaran Matematika Pokok Bahasan Statistik dengan
Menggunakan Pendekatan

Kontekstual (Contextual

Teaching and Learning $=C T L$ ) pada Siswa Kelas II di SMU Negeri $04 \quad$ Palembang. Palembang: Skripsi.

Rusman. 2010. Model-Model

PembelajaranMengembangkan

Profesionalisme Guru. Jakarta:

PT Rajagrafindo Persada.

Sandria, Vera. 2012. Menggunakan model pembelajaran kooperatif tipe group investigation pada mata pelajaran IPA di kelas IV SD Negeri 147 Palembang. Palembang: PTK (Tidak Dipublikasikan).

Sanjaya, Wina. 2005. Pembelajaran dalam Implementasi Kurikulum Berbasis Kompetensi. Bandung: Kencana Prenada Media Group.

Sardiman. 2007. Interaksi dan Motivasi Belajar Mengajar. Jakarta: PT. Raja Grafindo Persada.

Slameto. 1988. Evaluasi Pendidikan. Jakarta: PT. Rineka Cipta.

Sudjana, Nana. 1987. Dasar-dasar Proses Belajar Mengajar. Bandung: Sinar Baru Algensindo.

Sugiyono. 2007. Metode Penelitian Kuantitatif Kualitatif dan $R \& D$. Bandung: Alfabeta.

Trianto. 2007. Teori Kognitif Perilaku. Jakarta: Graha Ilmu.

Yuswadesi. 2007. Meningkatkan Hasil Belajar Matematika Siswa Kelas VII Melalui Pendekatafn CTL (Contextual Teaching and Learning). Palembang: Skripsi (Tidak Dipublikasikan). 